\title{
Sparrows (Passer domesticus L.) as intermediary hosts of Toxoplasma gondii in poultry farms from the "agreste" region of Pernambuco, Brazil ${ }^{1}$
}

\author{
Sineide M.O. Vilela ${ }^{2}$, José S.A. Silva², José W.P. Junior ${ }^{3}$, Érica P.B.X. \\ Moraes $^{2}$, Tomoe N. Saukas ${ }^{2}$, Luis F.P. Gondim ${ }^{4}$ and Rinaldo A. Mota ${ }^{2}$
}

\begin{abstract}
Vilela S.M.O., Silva J.S.A., Pinheiro Junior J.W., Moraes E.P.B.X., Saukas T.N., Gondim L.F.P. \& Mota R.A. 2011. Sparrows (Passer domesticus L.) as intermediary hosts of Toxoplasma gondii in poultry farms from the "agreste" region of Pernambuco, Brazil. Pesquisa Veterinária Brasileira 31(2):169-172. Laboratório de Doenças Infecto-Contagiosas dos Animais Domésticos, Departamento de Medicina Veterinária, Universidade Federal Rural de Pernambuco, Rua Dom Manoel de Medeiros s/ n, Dois Irmãos, Recife, PE 52171-900, Brazil. E-mail: rinaldo.mota@ hotmail.com

This paper aimed to identify Toxoplasma gondii infection in house sparrows (Passer domesticus, Linneaus 1758) coming from poultry farms in the "agreste" region of the Brazilian state of Pernambuco. 151 sparrows (Passer domesticus) captured in eight broiler, egg layer and commercial laying poultry farms, were used. Indirect hemagglutination test was used to research anti- $T$. gondii antibodies. Animals that presented titration of 1:16 were destined to DNA research through Polymerase Chain Reaction (PCR) technique, followed by Nested-PCR. It was observed that, from 151 analyzed samples. 91 (60.3\%) were reagents and $60(39.7 \%)$ were not reagents. It was verified, through analysis of the distribution of infected animals frequency per farm, that in only one farm (12.5\%) no animal reagent to $T$. gondii was captured. It was also observed that three $(30.00 \%)$ of the ten samples destined to DNA research for T. gondii were positive to PCR and four $(40.00 \%)$ were positive to Nested-PCR. Anti-T gondii antibodies occurrence and the molecular identification of the agent confirmed natural $T$. gondii infection in sparrows from poultry farms in Brazil. Other studies must be carried out to highlight the real importance of these animals in the epidemiological chain and their efficiency in the transmission of the parasite to felines. Therefore, researches that use parasite isolation and molecular techniques to determine genomic profile of the agent present in these poultry farms are needed.
\end{abstract}

INDEX TERMS: Epidemiology, diagnosis, toxoplasmosis.

RESUMO.- [Pardais (Passer domesticus L.) como hospedeiro intermediário do Toxoplasma gondii em granjas avícolas no agreste de Pernambuco.] Objetivou-se

\footnotetext{
${ }^{1}$ Received on July 14, 2010.

Accepted for publication on January 13, 2011.

Part of the Doctor thesis in Veterinary Sciences from the first author.

2 Departamento de Medicina Veterinária, Universidade Federal Rural de Pernambuco (UFRPE), Rua Dom Manoel de Medeiros s/n, Dois Irmãos. Recife, PE 52171-900, Brasil. *Autor para correspondência: rinaldo.mota@hotmail.com

${ }^{3}$ Unidade Acadêmica de Garanhuns, Universidade Federal Rural de Pernambuco, Av. Bom Pastor s/n, Boa Vista, Garanhuns, PE 55296-901, Brazil.

${ }^{4}$ Departamento de Patologia e Clínicas, Universidade Federal da Bahia, Av. Ademar de Barros 500, Ondina, Salvador, BA 40170-110, Brazil.
}

com este trabalho identificar a infecção por Toxoplasma gondii em pardais domésticos (Passer domesticus, Linneaus 1758) procedentes de granjas avícolas no agreste do estado de Pernambuco. Foram utilizados 151 pardais (Passer domesticus) capturados em oito granjas de frango de corte, matrizes e poedeiras comerciais. Para a pesquisa de anticorpos anti- $T$. gondi utilizou-se o teste de hemaglutinação indireta, aqueles animais que apresentaram titulação 1:16 foram encaminhados para pesquisa do DNA por meio da técnica de Reação em Cadeia da Polimerase (PCR) seguida do Nested-PCR. Das 151 amostras analisadas observou-se que 91 (60,3\%) foram reagentes e 60 (39,7\%) não reagentes. Na análise da distribuição de freqüência dos animais infectados por granja constatou-se que em apenas uma 
$(12,5 \%)$ não foi capturado animal reagente para $T$. gondii. Das dez amostras que foram encaminhadas para pesquisa do DNA do T. gondii, observou-se que três $(30,00 \%)$ foram positivas ao PCR e quatro (40,00\%) ao Nested-PCR. A ocorrência de anticorpos anti- T. gondiie a identificação molecular do agente confirmam a infecção natural por $T$. gondii em pardais em granjas avícolas no Brasil. Outros estudos devem ser conduzidos para elucidar a real importância destes animais na cadeia epidemiológica e sua eficiência da transmissão do parasito para felinos. Para tal serão necessárias pesquisas que utilizem técnicas de isolamento do parasito e molecular para determinar o perfil genômico do agente presente nestas granjas.

TERMOS DE INDEXAÇÃO: Epidemiologia, diagnóstico, toxoplasmose.

\section{INTRODUCTION}

Toxoplasma gondii (Nicole et Manceaux, 1908) is an intracellular protozoan potentially capable of invading and multiplying in any bird nucleic cell, including erythrocytes (Luzon et al. 1997).

T. gondii is classified as heteroxenous due to its characteristic of infecting a great variety of hosts. Even though its needs are strictly parasite, they may be met by the organism and the cells of most mammals and birds, different from stenoxenous parasites which are very restricted as to hosts (Rey 1991).

$T$. gondii infection frequency in different regions of the world is rather variable, and it might be connected to several factors, such as: cultural patterns of the population, feeding habits, age, rural or urban provenance, among others (Amendoeira et al. 1999).

The first studies carried out to determine toxoplasmosis incidence in birds were not very reliable, once the identification of the agent was performed solely with the help of a microscope. Thus, the agent could be mistaken for another protozoan with similar morphology (Beverley 1957).

Domestic fowls have been considered good indicators of soil contamination by $T$. gondii oocysts, being used as sentinel animals in regions of high human infection incidence, because of their pecking habit and susceptibility to the protozoan (Dubey et al. 2006).

Few works aiming at studying the infection of this parasite in sparrows (Passer domesticus) have been carried out. Pak (1972) performed the first T. gondii isolation in sparrows in the old Soviet Union, isolating the agent in 20 $(0.5 \%)$ of the samples. Then Catár (1974), Pak (1976) and Hejlicek et al. (1981) managed to isolate the agent in sparrows from Slovakia, Kazakhstan and the Czech Republic, respectively. The first serological survey of sparrows was carried out by Literák et al. (1997) in Poland and in the Czech Republic, through indirect immunofluorescence (RIFI), using 227 animals, of which 28 (12.3\%) were reagents.

According to Marobin et al. (2004), further researches on the role of domestic fowls in the disease epidemiology are needed. It is believed that domestic fowls are very important in $T$. gondii transmition, once their tissues and eggs are important sources of protein in general feline and human feeding.

Considering the lack of data in literature and the possible participation of sparrows as intermediary hosts, this work aimed at identifying Toxoplasma gondii coming from poultry farms in the "Agreste" region of the Brazilian state of Pernambuco, Brazil.

\section{MATERIAL AND METHODS}

A total of 151 sparrows (Passer domesticus) captured in eight broiler, egg layer and commercial laying poultry farms from six municipalities of the "Agreste" region of the state of Pernambuco, were used. Animal gender and age were not considered in this study.

To obtain serum, blood was collected by jugular venipuncture, using disposable syringes and needles, after physical restraining and previous local disinfection with alcohol at $70^{\circ} \mathrm{GL}$. Samples were conditioned in propylene tubes and stored at $-20^{\circ} \mathrm{C}\left(-4^{\circ} \mathrm{F}\right)$ until their processing.

The indirect hemagglutination test was used to research anti-T. gondii antibodies (kit WAMA - Diagnosis - Imuno-HAI Toxoplasmosis), according to the producer's recommendations for test performance and results interpretation. Ten animals were used in this stage of the research, and those presenting titration (1:16) in serology were destined to $T$. gondii DNA research. Central nervous system tissues samples (pool of brain, cerebellum and spinal cord) were used for DNA research by the polymerase chain reaction technique (PCR) followed by Nested-PCR.

All samples were submitted to DNA extraction with the commercial kit "Qiagen DNA Easy Blood and Tissues Kit" (Qiagen), according to the producer's protocol, in which each of the samples was cut into fragments of approximately $0.25 \mathrm{~g}$ and macerated in liquid nitrogen, and $180 \mu$ of buffer ATL and $20 \mathrm{~mL}$ of proteinase $\mathrm{K}$, mixed vigorously and incubated at $65^{\circ} \mathrm{C}$ for 10 minutes, were added in a microtube. Later, $200 \mu$ l of buffer $\mathrm{AL}$ and $200 \mathrm{~mL}$ of absolute ethanol was added and the mixture was transferred to a QIAamp column. Centrifugation was done at $6000 \mathrm{~g}$ for $1 \mathrm{~min}$. Microtube was disposed and the column was washed two times with buffers AW1 and AW2. DNA elution was carried out with $200 \mathrm{~mL}$ of buffer $\mathrm{AE}$ and incubated at room temperature for $5 \mathrm{~min}$ and then centrifuged at $6000 \mathrm{~g}$ for $1 \mathrm{~min}$. Extracted DNA was analyzed and quantified in agarose gel at $0.8 \%$, with molecular weight marker $1 \mathrm{~Kb}$, stained with ethidium bromide, visualized in ultraviolet light and photographed for verification of quality.

After DNA extraction, amplification reactions were carried out in a final volume of $12.5 \mathrm{~mL}$ with: $2.5 \mu \mathrm{L}$ of genomic DNA; $0.5 \mu \mathrm{L}$ of each primer at $10 \mu \mathrm{M}$ (Forward C1:5' - TCTTTAAAGCG TTCGTGGTC - 3' Reverse N 1: 5' - GGAACTGCATCCGTT CATGAG - 3), $2.5 \mu \mathrm{L}$ of Mili-Q ultrapure water and $6.25 \mu \mathrm{L}$ of MasterMix (mixture for PCR - Promega) according to the producer's protocol. The thermal profile of the reaction stages was carried out in thermocycler (Spalding et al. 2006). Fragments were amplified in 197pb and were detected by electrophoresis in agarose gel at $2 \%$, stained with ethidium bromide, visualized in ultraviolet light and photographed.

Negative and control samples were submitted to nested-PCR, using $1 \mu \mathrm{L}$ of simple PCR product and added to the mixture of 
reaction in a final volume of $12.5 \mathrm{~mL}$ with $0.5 \mu \mathrm{L}$ of each primer at

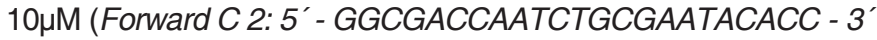
Reverse N 2: 5'- TGCATAGGTTGCAGTCACTG - 3; 4.75 $\mu \mathrm{L}$ of Mili-Q ultrapure water and 6.25 $\mu \mathrm{L}$ of MasterMix (mixture for PCRPromega) according to the supplier's protocol. The reactions cycle was adapted from the protocol described by Spalding et al. (2006) and consisted of denaturing the initial DNA at $95^{\circ} \mathrm{C}$ (4min) followed by 35 cycles at $95^{\circ} \mathrm{C}$ for 1 minute for denaturation, $62^{\circ} \mathrm{C}$ for 30 seconds for annealing, $72^{\circ} \mathrm{C}$ for 1 minute for elongation and a final period of elongation of 10 minutes at $72^{\circ} \mathrm{C}$. Fragments were amplified in $97 \mathrm{pb}$ and were detected by agarose gel electrophoresis at $2 \%$, stained with ethidium bromide, visualized in ultraviolet light and photographed.

Dispersion of absolute and relative frequency was carried out to analyze data (Sampaio 1998).

\section{RESULTS}

From the 151 analyzed samples, 91 (60.3\%) were reagent and $60(39.7 \%)$ were not reagent. Also, from the 10 samples destined to parasite DNA research, $3(30.00 \%)$ were positive to PCR and $4(40.00 \%)$ to Nested-PCR.

It was verified, through analysis of the distribution of infected animals frequency per farm, that in only one farm (12.5\%) no animal reagent to Toxoplasma gondii was captured, as shown in Table 1.

Table 1. Detection of anti-Toxoplasma gondii in domestic sparrows (Passer domesticus, Linneaus 1758) captured in poultry farms in the state Pernambuco, Brazil

\begin{tabular}{|c|c|c|c|c|c|c|}
\hline \multirow[t]{3}{*}{ Farm } & \multicolumn{4}{|c|}{$\mathrm{HI}$} & \multicolumn{2}{|c|}{ Total } \\
\hline & \multicolumn{2}{|c|}{ Reagent } & \multicolumn{2}{|c|}{ Not reagent } & \multirow[t]{2}{*}{ A.F. } & \multirow[t]{2}{*}{ R.F.(\%) } \\
\hline & A.F. & R.F.(\%) & A.F. & R.F.(\%) & & \\
\hline Farm 1 & - & & 2 & 100,0 & 2 & 100,0 \\
\hline Farm 2 & 16 & 47,1 & 18 & 52,9 & 34 & 100,0 \\
\hline Farm 3 & 11 & 78,6 & 3 & 21,4 & 14 & 100,0 \\
\hline Farm 4 & 19 & 70,4 & 8 & 29,6 & 27 & 100,0 \\
\hline Farm 5 & 5 & 83,3 & 1 & 16,7 & 6 & 100,0 \\
\hline Farm 6 & 26 & 55,3 & 21 & 44,7 & 47 & 100,0 \\
\hline Farm 7 & 7 & 100,0 & - & - & 7 & 100,0 \\
\hline Farm 8 & 7 & 50,0 & 7 & 50,0 & 14 & 100,0 \\
\hline
\end{tabular}

Convenction: A.F. = Absolute frequency; R.F. = Relative frequency; $\mathrm{HI}$ $=$ Indirect hemagglutination.

\section{DISCUSSION}

Results inferior to this study's were found by Literak et al. (1997) who evaluated 227 sparrows in Poland and in the Czech Republic, in which 28 (12.3\%) were reagents.

Experimentally induced sparrows are resistant to the parasite, but results may vary depending on inoculated Toxoplasma gondii strain, stage and number (Dubey 2002). Most sparrows parentally inoculated with a large quantity of tachyzoites in mice infected with $\mathrm{RH}$ strain soon died and other sparrows which received a relative high doses of oocysts $\left(10^{5}\right)$ also developed the acute disease and died (Dubey 2002). Literák et al. (1999) carried out an experiment with doses varying from $1-10^{4}$ oocysts in sparrows and observed that all animals remained clinically health, but presented low antibody titers.
It was observed the need of more detailed epidemiological investigations on the studied poultry farms, including chicken sample collection in order to know the importance of $T$. gondii infection on this species. Regarding infection in commercial chicken breeding in Brazil, it was observed low indexes of positive birds (Araújo et al. 1989), including the absence of infection in some localities (Meireles et al. 2003). These low indexes were attributed to the lowest probability of intensive farming fowls with the sources of infection. On the other hand, the high number of foci of infection observed in sparrows with this study highlights the need of further studies on broilers infection on these farms, once there is the risk of parasite transmission to men by ingesting poultry. Sparrows infection high levels may indicate high environmental contamination by this parasite which may infect other breeding species which are often present in these properties, causing considerable economic losses. Seroprevalence of natural infection in sparrows reported by Literák et al. (1997) varied according to number of infection sources.

No property presented history of cats presence, but considering that sparrows may use an area of approximately $10 \mathrm{~km}$, there is the possibility that they were infected somewhere else. Literák et al. (1997) reported in studies carried out for anti $T$. gondii antibodies research in sparrow in areas around the city of Lomianki, Poland, that human habitations are frequently inhabited by cats, which is a likely via of infection to sparrows. Another possibility for the infection of sparrows is the digestion of oocysts disposed in the environment (pasture and water) by wild felines. In Brazil, studies on wild animals such as skunk, capybara and canidae, were recently carried out, showing the occurrence of an important wild cycle (Yai et al. 2003, Canón-Franco et al. 2003, Genari et al. 2004).

Marobin et al. (2004) demonstrated by evaluating rheas (Rhea americana) in Rio Grande do Sul, Brazil, that $40,0 \%$ of properties had animals reagent to $T$. gondii, emphasizing the need of an epidemiological investigation of toxoplasmosis in these properties, specially about the presence or absence of cats, once they are not responsible for the agent dissemination.

The possibility of sparrow infection by the ingestion of rations contaminated by $T$. gondii oocysts, poorly stored in sheds or rations factories, may also be considered, once it is the cause for poultry contamination as well.

The infection rate in cats reflect the infection rate in fowls and rodent population because it is believed that cats are infected by the ingestion of these animals (Hill \& Dubey 2002). Like rodents, the fowls are considered important intermediary hosts of $T$. gondii, since they are the source of infection to feline (Dubey et al. 2002).

\section{CONCLUSION}

Anti-Toxoplasma gondii antibody occurrence and molecular identification of the agent confirm $T$. gondii natural infection in sparrows on poultry farms in Brazil. Other studies must be conducted in order to highlight these animals real 
importance in the epidemiological chain and their efficiency on transmitting the parasite to felines. In order to do so researches which use parasite and molecular isolation techniques to determine genomic profile of the agent present in these chicken farms, are needed.

Acknowledgements.- To WAMA lab for donating the Immuno - HAI Toxoplasmosis diagnosis kit, and to the Pró-Reitoria de Pesquisa e Pós-Graduação of Universidade Federal Rural de Pernambuco.

\section{REFERENCES}

Araújo F.A.P., Silva N.R.S., Chaplin E.L. \& Bigatti L.E. 1989. Prevalência de anticorpos toxoplasmáticos em frangos abatidos para consumo humano em Porto Alegre, Rio Grande do Sul. Arq. Fac. Vet. UFRGS 17:23-28.

Amendoeira M.R.R., Costa T. \& Spalding S.M. 1999. Toxoplasma gondii Nicole \& Manceaux, 1909 (Apicomplexa: Sarcocystidae) e a toxoplamose. Revta Souza Marques 1:15-29.

Beverley J.K.A. 1975. Toxoplasmosis. Vet. Rec. 69:337-341.

Catar G. 1974. Toxoplazmóza v ekologickyck podmienkack na Slovensku (in Slovakian). Biol. Práce. 20:1-138.

Cañón-Franco W.A., Yai L.E.O., Joppert A.M., Souza C.E., D'auria S.R.N., Dubey J.P. \& Gennari S.M. 2003. Seroprevalence of Toxoplasma gondii antibodies in the rodent cabybara (Hidrochoeris hidrocoeris) from Brazil. J. Parasitol. 89:850.

Dubey J.P. 2002. A review of toxoplasmosis in wild birds. Vet. Parasitol. 106:121-153.

Dubey J.P., Graham D.H., Blackston C.R., Lehmann T., Gennari S.M., Ragozo A.M.A., Nishi S.M., Shen S.K., Kwok O.C.H., Hill D.E. \& Thulliez P. 2002. Biological and genetic characterization of Toxoplasma gondii isolates from chickens (Gallus domesticus) from São Paulo: Unexpected findings. Int. J. Parasitol. 32:99-105.

Dubey J.P., Gennari S.M., Labruna M.B., Camargo L.M.A., Vianna M.C.B. \& Marcet P.L. 2006. Characterization of Toxoplasma gondii isolates free-range chickens from Amazon, Brazil. J. Parasitol. 92:3640.

Gennari S.M., Cañón-Franco W.A., Yai L.E.O., Souza S.L.P., Santos L.C., Farias N.A.R., Ruas J., Rossi F.W. \& Gomes A.A.B. 2004. Sero-prevalence of Toxoplasma gondii antibodies from wild canids from Brazil. Vet. Parasitol. 121:337-340.
Hejlíceck K., Prosec F. \& Treml F. 1981. Isolation of Toxoplasma gondii in free-living small mammals and birds. Acta Vet. Brno 50:233-236.

Hill D. \& Dubey J.P. 2002. Toxoplasma gondii: Transmission, diagnosis and prevention. Clin. Microbiol. Infect. 8:634-640.

Litérak I., Pinowski J., Anger M., Juricová Z., Kyu-Hwang H. \& Romanowski J. 1997. Toxoplasma gondii antibodies in house sparrows (Passer domesticus) and tree sparrows (P. montanus). Avian Pathol. 26:823827.

Literák I., Sedlák K., Juricová Z. \& Pavlásek I. 1999. Experimental toxoplasmosis in house sparrows (Passer domesticus). Avian Pathol. 28:363-368.

Luzon M., Miro G. \& Quintanilla Gonzallo A. 1997. Etiologia y Biologia: toxoplasmosis. Trat. Patol. Produc. Ovin. 73:19-34.

Marobin L., Flôres M.L., Rizzatti B.B., Segabinazi S.D., Lagaggio V.R.A., Grigulo M. \& Scalco M.A. 2004. Prevalência de anticorpos para Toxoplasma gondii em emas (Rhea americana) em diferentes criatórios do Estado do Rio Grande do Sul. Braz. J. Vet. Res. Anim. Sci. 41: 5-9.

Meireles L.R., Galisteo Junior A.F. \& Andrade Junior H.F. 2003. Serological survey of antibodies to Toxoplasma gondii in food animals from São Paulo State, Brazil. Braz. J. Vet. Res. Anim. Sci. 40:267271.

Pak S.M. 1972. Toxoplasmosis of sparrow (in Russian). Contributions Nat. Nidality Dis. 4:78-94.

Pak S.M. 1976. Toxoplasmosis of birds in Kazakhstan (in Russian). Nauka Publishing: Alma-Ata. 115p.

Rey L. 1991. Os ciclos parasitários e a teoria dos focos naturais, p.5456. In: Rey L. (Ed.), Parasitologia: parasitos e doenças parasitárias do homem nas Américas e África. Guanabara Koogan, Rio de Janeiro.

Spalding S.M., Angel S.O. \& Amendoeira M.R.R. 2006. Toxoplasmose, p.102-111. In: Rossetti M.L., Silva C.M.D. \& Rodrigues J.J.S. (Eds), Doenças Infecciosas: diagnóstico molecular. Guanabara Koogan, Rio de Janeiro.

Sampaio I.B.M. 2003. Estatística Aplicada à Experimentação Animal. Funep, Belo Horizonte. 218p.

Yai L.E.O., Cañón-Franco W.A., Geraldi V.C., Summa M.E.L., Camargo M.C.G.O., Dubey J.P. \& Gennari S.M. 2003. Seroprevalence of $\mathrm{Ne}-$ ospora caninum and Toxoplasma gondii antibodies in the South American opossum (Didelphis marsapialis) from the city of São Paulo, Brazil. J. Parasitol. 89:870-871. 